\title{
GAMBARAN PERTUMBUHAN DAN PERKEMBANGAN ANAK USIA 12 BULAN YANG DIBERI ASI EKSKLUSIF DAN YANG TIDAK DIBERI ASI EKSKLUSIF DI DESA BARUMEKAR KECAMATAN PARUNGPONTENG KABUPATEN TASIKMALAYA TAHUN 2017
}

\author{
Mutiah, AMd.Keb ${ }^{1)}$ \\ Mutianurdiana7@gmail.com \\ Hapi Apriasih, SST, M.Kes ${ }^{2)}$ \\ py.anbyan@gmail.com
}

\begin{abstract}
ABSTRAK
Pemberian ASI Eksklusif sangatlah penting bagi bayi karena nutrisi yang baik pada masa bayi, dapat menyebabkan kesehatan yang baik, pertumbuhan dan perkembangan yang optimal selama beberapa bulan pertama kehidupan. Hasil studi pendahuluan yang peneliti lakukan di Kabupaten Tasikmalaya tahun 2016 cakupan ASI Eksklusif adalah 33,71 \% dari target sebesar 65,5\%, dan di Wilayah Kerja Puskesmas Parungponteng Kabupaten Tasikmalaya merupakan puskesmas ke-1 terendah masalah cakupan ASI Eksklusif sebesar $8,1 \%$. Tujuan penelitian ini adalah untuk mengetahui gambaran pertumbuhan dan perkembangan Anak Usia 12 bulan yang diberi ASI Eksklusif dan yang tidak diberi ASI Eksklusif. Penelitian ini bermanfaat sebagai masukkan bagi ibu untuk meningkatkan kesadaran pentingnya pemberian ASI Eksklusif.

Penelitian ini menggunakan metode deskriptif dengan pendekatan observasional. Penelitian ini dilaksanakan di Desa Barumekar Kecamatan Parungponteng dengan waktu penelitian bulan Maret-April 2017. Teknik pengambilan sampel menggunakan purposive sampling, dengan jumlah responden anak usia 12 bulan yang diberi ASI Eksklusif sebanyak 11 orang, dan yang tidak diberi ASI Eksklusif sebanyak 19. Instrumen penelitian yang digunakan adalah lembar observasi, KMS dan KPSP. Analisa data menggunakan analisa univariat dengan menggunakan rumus persentase.

Hasil penelitian menunjukkan bahwa pertumbuhan anak usia 12 bulan yang diberikan ASI Eksklusif ada pada kategori normal (100\%), sedangkan yang tidak diberi ASI Eksklusif ada pada kategori tidak normal (36,8\%). Perkembangan anak usia 12 bulan yang diberi ASI Eksklusif ada pada kategori sesuai (100\%), sedangkan yang tidak diberi ASI Eksklusif hanya beberapa orang yang meragukan $(15,8 \%)$.

Kesimpulan dari penelitian ini adalah bahwa pertumbuhan dan perkembangan bayi usia 12 bulan dapat dipengaruhi oleh pemberian ASI Eksklusif. Disarankan masyarakat/ ibu yang mempunyai anak usia 12 bulan untuk memperdalam mengenai manfaat ASI Eksklusif, dan harus memberikan ASI Eksklusif minimal 6 bulan setelah bayi baru lahir, agar pertumbuhan dan perkembangan anak optimal
\end{abstract}

Kata Kunci : ASI Eksklusif, ASI Non Eksklusif, Pertumbuhan, Perkembangan 


\section{A. PENDAhuluan}

Persiapan untuk menghasilkan generasi yang sehat dan cerdas diperlukan persiapan sejak dini, salah satunya adalah pemberian nutrisi yang baik yang dimulai sejak lahir. Pemberian nutrisi yang baik bagi anak baru lahir adalah dengan memberikan ASI Eksklusif (Tyas, 2013).

Pertumbuhan dan perkembangan anak merupakan salah satu indikator untuk melihat anak tersebut sehat atau mengalami kelainan. Banyak faktor yang mempengaruhi pertumbuhan dan perkembangan anak yaitu : nutrisi yang baik, pola asuh orang tua, lingkungan, sosial ekonomi keluarga, jenis kelamin dan genetik (Sofyana, 2011).

\section{Cakupan pemberian ASI} Eksklusif di Indonesia masih belum mencapai target, hal ini terlihat dari data yang diperoleh Riset Kesehatan Dasar (2010) menyebutkan bahwa cakupan pemberian ASI Eksklusif pada tahun 2013 sebesar 54,3\%, sedangkan target cakupan pemberian ASI Eksklusif sebesar $80 \%$. Padahal secara teori pemberian ASI Eksklusif sangatlah penting bagi bayi karena nutrisi yang baik pada masa bayi, memungkinkan kesehatan yang baik, pertumbuhan dan perkembangan yang optimal selama beberapa bulan pertama kehidupan dan membiasakan bayi agar memiliki kebiasaan makan yang baik pada masa selanjutnya (Roesli, 2008).

Dampak pemberian ASI Eksklusif pada anak adalah tercapainya pertumbuhan dan perkembangan serta kecerdasan yang optimal, sedangkan dampak tidak diberikan ASI Eksklusif memiliki risiko kematian karena diare 3,94 kali lebih besar dibandingkan bayi yang mendapat ASI eksklusif. Faktorfaktor yang mempengaruhi terhadap kegagalan pemberian ASI Eksklusif adalah kurangnya pengetahuan ibu tentang manfaat ASI Eksklusif, ibu bekerja, motivasi yang kurang dari ibu, dan banyaknya produsen susu formula (Utaminingrum \& Sartono, 2012).

Penelitian yang dilakukan oleh Juli Jumadi (2015) menjelaskan bahwa anak yang diberi ASI Eksklusif perkembangannya lebih baik dibandingkan dengan anak yang diberi ASI non eksklusif di posyandu wilayah kerja puskesmas Karanggede, kabupaten Boyolali. Pemberian ASI secara eksklusif mempengaruhi perkembangan karena ASI mempunyai kandungan yang baik untuk perkembangan anak selain itu pemberian ASI juga dapat menjadi stimulasi untuk perkembangan anak hal ini dikarenakan pada saat menyusui anak dan ibu berinteraksi sehingga membentuk perkembangan anak. Selain dari pemberian ASI juga dipengaruhi oleh adanya stimulasi dari lingkungan sekitar.

Hasil studi pendahuluan yang peneliti lakukan di Kabupaten Tasikmalaya tahun 2016 cakupan ASI Eksklusif adalah 33,71 \% dari target sebesar 65,5\%, dan di Wilayah Kerja Puskesmas Parungponteng Kabupaten Tasikmalaya merupukan puskesmas ke1 terendah masalah cakupan ASI Eksklusif sebesar $8,1 \%$ dan belum mencapai target. 
Berdasarkan hasil wawancara dengan petugas kesehatan di Desa Barumekar Kecamatan Parungponteng diperoleh data bayi ada 30 orang, dari jumlah tersebut sebanyak 19 orang $(63,3 \%)$ tidak ASI Eksklusi12) sebanyak 11 orang $\left.(36,7 \%)^{3}\right)$ eksklusif, adapun bayi yang termasuk gizi kurang ada 3 orang dan penyakit yang banyak diderita bayi saat ini adalah ISPA dan diare, hal ini kemungkinan karena ibu tidak memberi ASI Eksklusif. Peneliti juga melakukan wawancara dengan beberapa ibu yang mempunyai bayi, diperoleh bahwa hampir semua ibu yang diwawancarai tidak memberikan ASI Eksklusif sehingga berpengaruh terhadap pertumbuhan dan perkembangan bayi seperti berat badan, tinggi badan, lingkar kepala, kemampuan motorik halus anak.

Berdasarkan uraian 4$)$
belakang tersebut, penulis $\left.\mathrm{t}^{5}\right)$

melakukan penelitian me

"Gambaran Pertumbuhan

Perkembangan Anak Usia 12

Yang Diberi ASI Eksklusif dan

Tidak Diberi ASI Eksklusif di7)

Barumekar Kecamatan Parungp 8)

Kabupaten Tasikmalaya Tahun 2017".

\section{B.METODOLOGI PENELITIAN}

1. Desain Penelitian

Desain penelitian yang digunakan dalam penelitian ini adalah deskriptif, dengan pendekatan observasional yaitu penelitian yang dilakukan hanya mendeskripsikan dari variabel yang diobservasi oleh peneliti.

1. Waktu dan Tempat Penelitian
Penelitian ini telah dilaksanakan pada bulan Maret-April tahun 2017. Penelitian ini telah dilaksanakan di Desa Barumekar Kecamatan Parungponteng Kabupaten Tasikmalaya.

\section{Populasi dan Sampel}

Populasi dalam penelitian ini adalah anak usia 12 bulan yang diberi ASI Eksklusif sebanyak 11 orang, dan yang tidak diberi ASI Eksklusif sebanyak 19 orang di Desa Barumekar Kecamatan Parungponteng Kabupaten Tasikmalaya. Teknik pengambilan sampel dalam penelitian ini adalah Purposive Sampling yaitu teknik pengambilan sampel yang dilakukan dengan sengaja dengan memperhatikan karakteristik yang telah diketahui sebelumnya yaitu seluruh anak usia 12 bulan berjumlah 30 orang.

\section{Prosedur Pengambilan Data}

Pengambilan data dalam penelitian ini berupa data primer untuk melihat pertumbuhan bayi dengan observasik dan KMS serta perkembangan bayi dilihat dari hasil observasi dan KPSP.

5. Instrumen Penelitian

Sesuai dengan prosedur pengambilan data, maka instrumen dalam penilitian ini adalah lembar observasi dan KMS yang digunakan untuk mengukur pertumbuhan bayi, KPSP digunakan untuk melihat perkembangan bayi, dan lembar ceklist untuk mengetahui pemberian ASI.

\section{Pengolahan dan Analisis Data}


Analisa univariat dilakukan untuk mendeskipsikan variabel penelitian yaitu mendeskripsikan pertumbuhan dan perkembangan anak usia 12 bulan antara yang diberi ASI Eksklusif dan yang tidak diberi ASI Eksklusif.

\section{HASIL PENELITIAN}

Penelitian tentang gambaran pertumbuhan dan perkembangan anak usia 12 bulan antara yang diberi ASI Eksklusif dan yang tidak ASI Eksklusif telah dilaksanakan pada 30 orang anak di Desa Barumekar Kecamatan Parungponteng Kabupaten Tasikmalaya pada bulan Maret-April 2017. Sebelum menjelaskan hasil penelitian, terlebih dahulu akan dijelaskan mengenai karakteristik responden sebagai berikut :

1. Karakteristik Ibu yang Mempunyai Anak Usia 12 Bulan

Tabel 5.1 Umur Ibu yang Mempunyai Anak Usia 12 di Desa Barumekar Kecamatan Parungponteng Kabupaten Tasikmalaya

\begin{tabular}{ccccc}
\hline N & $\begin{array}{c}\text { Rata } \\
\text {-rata }\end{array}$ & Min & Mak & Sd \\
\hline 30 & 30 & 24 & 37 & 4,3 \\
\hline
\end{tabular}

berdasarkan Tabel 5.1 menunjukkan bahwa rata-rata umur ibu yang mempunyai anak usia 12 bulan yaiu 30 tahun, umur minimal 24 tahun, umur maksimal 37 tahun, dengan standar deviasi 4,3
Tabel 5.2 Pendidikan Ibu yang

Mempunyai Anak Usia 12 di

Desa Barumekar Kecamatan

Parungponteng Kabupaten Tasikmalaya

\begin{tabular}{ccc}
\hline Kategori & Frekuensi & Persentase \\
\hline SD & 6 & 20,0 \\
SMP & 8 & 26,7 \\
SMA & 12 & 40,0 \\
S-1 & 4 & 13,3 \\
\hline Jumlah & 30 & 100 \\
\hline
\end{tabular}

Berdasarkan Tabel 5.2 menunjukkan bahwa tingkat pendidikan ibu yang mempunyai anak 12 bulan adalah tamatan SMA sebanyak 12 orang $(40,0 \%)$.

Tabel 5.3 Pekerjaan Ibu yang Mempunyai Anak Usia 12 di

Desa Barumekar Kecamatan Parungponteng Kabupaten Tasikmalaya

\begin{tabular}{ccc}
\hline Kategori & Frekuensi & Persentase \\
\hline IRT & 21 & 70,0 \\
Tani & 5 & 16,7 \\
Guru & 4 & 13,3 \\
\hline Jumlah & 30 & 100 \\
\hline
\end{tabular}

Berdasarkan Tabel 5.3 menunjukkan bahwa pekerjaan ibu yang mempunyai anak 12 bulan adalah ibu rumah tangga yaitu sebanyak 21 orang $(70,0 \%)$. 
Tabel 5.4 Riwayat Persalinan Ibu yang Mempunyai Anak Usia 12 di Desa Barumekar Kecamatan Parungponteng Kabupaten Tasikmalaya

\begin{tabular}{|c|c|c|}
\hline Kategori & Frekuensi & Persentase \\
\hline Normal & 30 & 30 \\
\hline Tidak normal & 0 & \\
\hline Jumlah & 30 & 100 \\
\hline
\end{tabular}

Tabel 5.5 Riwayat Penyakit Ibu yang Mempunyai Anak Usia 12 di Desa Barumekar Kecamatan Parungponteng Kabupaten Tasikmalaya

\begin{tabular}{ccc}
\hline Riwayat Penyakit & Frekuensi & Persentase \\
\hline Tidak & 26 & 86,7 \\
Hipertensi & 4 & 13,3 \\
\hline Jumlah & 30 & 100
\end{tabular}

Berdasarkan Tabel 5.5 menunjukkan bahwa riwayat penyakit ibu pada ibu yang mempunyai anak 12 bulan tidak mempunyai riwayat penyakit sebanyak 26 orang $(86,7 \%)$.

Tabel 5.6 Riwayat Penyakit Anak Usia 12 di Desa Barumekar Kecamatan Parungponteng Kabupaten Tasikmalaya

\begin{tabular}{ccc}
\hline Riwayat Penyakit & Frekuensi & Persentase \\
\hline Tidak & 21 & 70,0 \\
Febris & 5 & 16,7 \\
Diare & 4 & 13,3 \\
\hline Jumlah & 30 & 100 \\
\hline
\end{tabular}

Berdasarkan Tabel 5.6 menunjukkan bahwa riwayat penyakit anak usia 12 bulan sebanyak 21 orang $(70,7 \%)$ tidak mempunyai riwayat penyakit 


\section{Pertumbuhan Anak Usia 121 Bulan}

Tabel 5.7 Tabulasi Silangan Pertumbuhan Anak Usia 12 Bulan Berdasarkan Berat Badan Antara yang Diberi ASI Eksklusif dan Tidak Diberi ASI Eksklusif Di Desa Barumekar Kecamatan Parungponteng Kabupaten Tasikmalaya Periode MaretApril Tahun 2017

\begin{tabular}{ccccccc}
\hline & \multicolumn{6}{c}{ Berat Badan } \\
Pemberian ASI & Normal & \multicolumn{1}{c}{ Tidak normal } & Total \\
\cline { 2 - 7 } & $\mathrm{f}$ & $\%$ & $\mathrm{f}$ & $\%$ & $\mathrm{~F}$ & $\%$ \\
ASI Eksklusif & 11 & 100 & 0 & 0 & 11 & 100 \\
Tidak ASI & 12 & 63,2 & 7 & 36 & 1 & 100 \\
Eksklusif & & & &, 8 & 9 & \\
\hline Jumlah & 23 & 76,7 & 7 & 23,3 & 3 & 100 \\
& & & & & 0 & \\
\hline
\end{tabular}

Berdasarkan Tabel 5.7 menunjukkan bahwa pertumbuhan bayi usia 12 bulan berdasarkan berat badan diperoleh bahwa bayi yang diberi ASI Eksklusif seluruhnya ada pada kategori normal (100\%), sedangkan bayi usia 12 bulan yang tidak diberi ASI Eksklusif sebanyak 12 orang $(63,2 \%)$ ada pada kategori normal dan sebanyak 7 orang $(36,8 \%)$ ada pada kategori tidak normal.

Tabel 5.8 Tabulasi Silangan Pertumbuhan Anak Usia 12 Bulan Berdasarkan Tinggi Badan Antara yang Diberi ASI Eksklusif dan Tidak Diberi ASI Eksklusif Di Desa Barumekar Kecamatan Parungponteng Kabupaten Tasikmalaya Periode MaretApril Tahun 2017

\begin{tabular}{cccccccc}
\hline \multirow{2}{*}{ Pemberian ASI } & \multicolumn{7}{c}{$\begin{array}{c}\text { Tinggi Badan } \\
\text { Tidak normal }\end{array}$} \\
& Normal & \multicolumn{5}{c}{ Total } \\
\cline { 2 - 7 } & $\mathrm{f}$ & $\%$ & $\mathrm{f}$ & $\%$ & $\mathrm{f}$ & $\%$ \\
ASI Eksklusif & 11 & 100 & 0 & 0 & 11 & 100 \\
Tidak ASI & 15 & 78,9 & 4 & 21, & 19 & 100 \\
Eksklusif & & & & 1 & & \\
\hline Jumlah & 26 & 86,7 & 4 & 13, & 30 & 100 \\
& & & & 3 & & \\
\hline
\end{tabular}


Berdasarkan Tabel 5.8 menunjukkan bahwa pertumbuhan bayi usia 12 bulan berdasarkan tinggi badan diperoleh bahwa bayi yang diberi ASI Eksklusif seluruhnya ada pada kategori normal (100\%), sedangkan bayi usia 12 bulan yang tidak diberi ASI Eksklusif sebanyak 15 orang $(78,9 \%)$ ada pada kategori normal dan sebanyak 4 orang $(21,1 \%)$ ada pada kategori tidak normal.

Tabel 5.9 Tabulasi Silangan Pertumbuhan Anak Usia 12 Bulan Berdasarkan Lingkar Kepala Antara yang Diberi ASI Eksklusif dan Tidak Diberi ASI Eksklusif Di Desa Barumekar Kecamatan Parungponteng Kabupaten Tasikmalaya Periode Maret-April Tahun 2017

\begin{tabular}{ccccccc}
\hline & \multicolumn{7}{c}{ Lingkar Kepala } \\
Pemberian ASI & Normal & \multicolumn{1}{c}{ Tidak normal } & Total \\
\cline { 2 - 7 } & $\mathrm{f}$ & $\%$ & $\mathrm{f}$ & $\%$ & $\mathrm{f}$ & $\%$ \\
ASI Eksklusif & 11 & 100 & 0 & 0 & 11 & 100 \\
Tidak ASI & 12 & 63,2 & 7 & 36,8 & 19 & 100 \\
Eksklusif & 23 & 76,7 & 7 & 23,3 & 30 & 100 \\
\hline Jumlah & & & & & & \\
\hline
\end{tabular}

Berdasarkan Tabel 5.9 menunjukkan bahwa pertumbuhan bayi usia 12 bulan berdasarkan lingkar kepala diperoleh bahwa bayi yang diberi ASI Eksklusif seluruhnya ada pada kategori normal (100\%), sedangkan bayi usia 12 bulan yang tidak diberi ASI Eksklusif sebanyak 12 orang $(63,2 \%)$ ada pada kategori normal dan sebanyak 7 orang $(36,8 \%)$ ada pada kategori tidak normal.

\section{Perkembangan Anak Usia 12 Bulan}

Tabel 5.10 Distribusi Frekuensi Perkembangan Anak Usia 12 Bulan Di Desa Barumekar Kecamatan Parungponteng Kabupaten Tasikmalaya Periode Maret-April Tahun 2017

\begin{tabular}{crccc}
\hline Perkembangan & \multicolumn{2}{c}{ ASI Eksklusif } & \multicolumn{2}{c}{ Tidak ASI } \\
& \multicolumn{3}{c}{ Eksklusif } \\
& $\mathrm{f}$ & $\%$ & $\mathrm{f}$ & $\%$ \\
\hline Sesuai & 11 & 100 & 16 & 84,2 \\
Meragukan & 0 & 0 & 3 & 15,8 \\
Menyimpang & 0 & 0 & 0 & 0 \\
\hline Jumlah & 11 & 100 & 19 & 100 \\
\hline
\end{tabular}

Berdasarkan Tabel 5.10 menunjukkan bahwa anak usia 12 bulan di Desa Barumekar Kecamatan Parungponteng Kabupaten Tasikmalaya yang diberikan ASI Eksklusif 
perkembangannya sesuai yaitu sebanyak 11 orang (100,0\%), sedangkan anak usia 12 bulan yang tidak diberi ASI Eksklusif sebanyak 16 orang $(84,2 \%)$ ada pada kategori sesuai, sedangkan sebanyak 3 orang $(15,9 \%)$ perkembangannya meragukan

\section{E. PEMBAHASAN}

1. Karakteristik Responden Umur Responden

Berdasarkan hasil penelitian menunjukkan bahwa rata-rata umur ibu yang mempunyai anak usia 12 bulan yaiu 30 tahun. Ini menunjukkan bahwa usia responden termasuk usia produktif yang dapat memberikan dampak terhadap pertumbuhan dan perkembangan anak khususnya usia 12 bulan. Hal ini dapat dimengerti karena semakin bertambah umur ibu maka dia akan belajar untuk semakin bertanggung jawab terhadap anak juga semakin banyak pengalaman dan informasi mengenai kesehatan. Usia adalah lama waktu hidup atau ada (sejak dilahirkan atau diadakan) (Hoetomo, 2005).

Tingkat Pendidikan

Berdasarkan hasil penelitian menunjukkan bahwa tingkat pendidikan ibu yang mempunyai anak 12 bulan adalah tamatan SMA sebanyak 12 orang (40,0\%). Hal ini menggambarkan bahwa tingkat pendidikan ibu cukup baik dalam mengadopsi informasi mengenai pertumbuhan dan perkembangan anak. Semakin tinggi tingkat pendidikan ibu semakin baik dalam pola asuh.

Pendidikan pada dasarnya adalah proses komunikasi yang didalamnya mengandung transformasi pengetahuan, nilai-nilai dan keterampilan- keterampilan, didalam dan diluar sekolah yang berlangsung sepanjang hayat (life long procces), dari generasi ke generasi. Pendidikan sangat bermakna bagi kehidupan individu, masyarakat, dan suatu bangsa. Pendidikan sebagai gejala manusiawi dan sekaligus upaya sadar, didalamnya tidak terlepas dari keterbatasan-keterbatasan yang dapat melekat pada peserta didik, pendidik, interaksi pendidikan, serta pada lingkungan dan sarana pendidikan (Dwi Siswoyo, 2008).

Pendidikan bagi kehidupan umat manusia merupakan kebutuhan mutlak yang harus dipenuhi sepanjang hayat. Tanpa pendidikan sama sekali mustahil suatu kelompok manusia dapat hidup berkembang sejalan dengan aspirasi (cita-cita) untuk maju, sejahtera dan bahagia menurut konsep pandangan hidup mereka (Fuad Ihsan, 2008).

Pekerjaan

Berdasarkan hasil penelitian menunjukkan bahwa pekerjaan ibu yang mempunyai anak 12 bulan adalah ibu rumah tangga yaitu sebanyak 21 orang. Pekerjaan dapat memberikan dampak terhadap pertumbuhan dan perkembangan anak, ibu yang bekerja lebih maksimal dalam memantau pertumbuhan dan perkembangan anak dibandingkan dengan ibu yang bekerja. Selain lebih optimal dalam memberikan ASI Eksklusif, ibu yang tidak bekerja lebih banyak waktu dalam mengawasi anaknya.

Pekerjaan adalah sesuatu yang dilakukan untuk mencari nafkah, pencaharian. Dewasa ini perempuan mendapat kesempatan bekerja yang semakin terbuka. Alasan yang mendasar seseorang perempuan untuk memiliki pekerjaan tidak sama antara satu dengan yang lain. 
Alasan yang umum dijumpai adalah karena kebutuhan keuangan untuk memperkaya pengalaman dan pengetahuan pribadi, hasrat pribadi (Priyoto, 2014).

Pekerjaan adalah sesuatu yang harus dilakukan terutama untuk menunjang kehidupannya dan kehidupan keluarga. Pekerjaan bukanlah sumber kesenangan, tetapi lebih banyak merupakan cara mencari nafkah yang membosankan, berulang dan banyak tantangan. Sedangkan bekerja umumnya merupakan kegiatan yang menyita waktu. Bekerja bagi ibu-ibu akan mempunyai pengaruh terhadap kehidupan keluarga (Wawan, 2010).

\section{Pertumbuhan Anak Usia 12 Bulan}

Berat Badan

Berdasarkan hasil penelitian menunjukkan bahwa pertumbuhan bayi usia 12 bulan berdasarkan berat badan diperoleh bahwa bayi yang diberi ASI Eksklusif seluruhnya ada pada kategori normal (100\%), sedangkan bayi usia 12 bulan yang tidak diberi ASI Eksklusif sebanyak 12 orang $(63,2 \%)$ ada pada kategori normal dan sebanyak 7 orang $(36,8 \%)$ ada pada kategori tidak normal.

Masih adanya ibu yang tidak memberikan ASI Eksklusif kepada anaknya disebabkan berbagai faktor diantaranya adalah kurangnya pengetahuan ibu/ keluarga tentang manfaat ASI Eksklusif, pola asuh orang tua yang kurang baik, peran petugas kesehatan yang belum optimal dalam memberikan pelayanan terutama mengenai pemberian ASI Eksklusif.

Berdasarkan data tersebut peneliti berasumsi bahwa bayi yang diberi ASI Eksklusif cenderung mempunyai berat badan yang normal sesuai dengan pertumbuhannya, berbeda dengan bayi yang tidak diberi ASI Eksklusif pertumbuhan berat badannya cenderung melebihi batas normal. Hal ini disebabkan karena kandungan nutrisi pada ASI Eksklusif lebih tinggi dibandingkan dengan nutrisi pada susu formula

Anak yang mengkonsumsi susu formula cenderung berat badannya melebihi batas normal dari usia anak. Ini terjadi karena pada anak yang diberikan susu formula.

Bayi yang diberi susu formula mendapatkan 71 atau 89 gram lebih berat badannya per bulan dibandingkan yang diberi ASI eksklusif. Sehingga peningkatan berat badan per bulan yaitu 729 gram untuk bayi dengan ASI ekslusif dan 780 gram untuk bayi dengan susu botol atau susu formula (Ruowei Li, 2012). Pada bulan ke 4, bayi dengan ASI ekslusif mengonsumsi $20 \%$ kalori lebih rendah per harinya dibandingkan bayi dengan susu formula (Dennison, 2006).

Penelitian Hester et al (2012) menyebutkan rata-rata volume susu formula yang dikonsumsi pada hakekatnya lebih tinggi daripada volume dari ASI. Dikarenakan lebih besarnya asupan volume susu dan lebih tingginya kandungan energi pada susu formula, rata-rata asupan energi pada hari ke 14 sampai 6 minggu kehidupannya pada bayi dengan susu formula lebih tinggi yaitu $513 \mathrm{kkal} / \mathrm{hari}$ jika dibandingkan bayi dengan ASI yaitu $440 \mathrm{kkal} / \mathrm{hari}$.

Penelitian ini sejalan dengan penelitian Tyas pada tahun 2013 yang berjudul hubungan antara pemberian ASI eksklusif dan ASI non eksklusif dengan pertumbuhan berat badan bayi 0-6 bulan di Desa Giripurwo Wonogiri yang menyatakan bayi dengan pertumbuhan berat badan baik yang mendapat ASI eksklusif berjumlah 40 (55,56\%) sedangkan yang mendapat ASI non eksklusif berjumlah $8(11,11 \%)$ sedangkan bayi dengan pertumbuhan berat badan tidak baik yang mendapat ASI eksklusif berjumlah $6(28,85 \%)$ dan yang mendapat ASI non 
eksklusif berjumlah $18(25,00 \%)$ yang artinya pada bayi yang mengalami pertumbuhan berat badan baik terbanyak pada bayi yang mendapat ASI eksklusif (Tyas, 2013).

Tinggi Badan

Berdasarkan hasil penelitian menunjukkan bahwa pertumbuhan bayi usia 12 bulan berdasarkan tinggi badan diperoleh bahwa bayi yang diberi ASI Eksklusif seluruhnya ada pada kategori normal (100\%), sedangkan bayi usia 12 bulan yang tidak diberi ASI Eksklusif sebanyak 15 orang $(78,9 \%)$ ada pada kategori normal dan sebanyak 4 orang $(21,1 \%)$ ada pada kategori tidak normal.

Berdasarkan data tersebut peneliti berpendapat bahwa bayi yang diberi ASI Eksklusif cenderung mempunyai tinggi badan yang normal dibandingkan yang tidak diberi ASI Eksklusif, ini terjadi karena dalam kandungan ASI Eksklusif terdapat banyak nutrisi yang mendukung terhadap pertumbuhan tinggi badan.

Pengukuran panjang badan dapat dilakukan dengan sangat mudah untuk menilai gangguan pertumbuhan dan perkembangan anak. Panjang badan anak baru lahir normal adalah 45-50 cm dan berdasarkan kurva pertumbuhan yang diterbitkan oleh National Center for Health Statistics (NCHS), anak akan mengalami penambahan panjang badan sekitar 2,5 cm setiap bulannya (Wong dkk, 2008). Penambahan tersebut akan berangsur- angsur berkurang sampai usia 9 tahun, yaitu hanya sekitar $5 \mathrm{~cm} /$ tahun dan penambahan ini akan berhenti pada usia 1820 tahun (Nursalam dkk., 2005).

Hasil penelitian ini sejalan dengan penelitian yang dilakukan oleh Harjanto (2016) yang menyatakan bahwa terdapat perbedaan rerata panjang badan bayi berusia 6 sampai 12 bulan yang diberikan ASI eksklusif dengan yang tidak diberikan ASI eksklusif di wilayah kerja puskesmas Rajabasa Indah Bandar Lampung.

Panjang badan memberikan gambaran pertumbuhan sejalan dengan pertambahan umur dan tidak terpengaruh perubahan yang mendadak, seperti jangkitan penyakit yang tidak berlangsung kronis maupun perubahan jenis konsumsi makanan (Soehartiningsih, 2010).

Ukuran panjang badan yang rendah umumnya menunjukkan keadaan gizi yang kurang akibat kekurangan energi dan protein. Selain itu panjang badan bayi lahir juga dipengaruhi oleh ukuran tubuh

dan status gizi ibu saat masa kehamilan. Ibu dengan ukuran tubuh yang kecil memiliki risiko untuk melahirkan bayi yang juga kecil. Pemberian makanan tambahan sejak usia 0-36 bulan dapat meningkatkan pertumbuhan panjang badan secara bermakna (Jacob, 2008).

Lingkar Kepala

Berdasarkan hasil penelitian menunjukkan bahwa pertumbuhan bayi usia 12 bulan berdasarkan lingkar kepala diperoleh bahwa bayi yang diberi ASI Eksklusif seluruhnya ada pada kategori normal (100\%), sedangkan bayi usia 12 bulan yang tidak diberi ASI Eksklusif sebanyak 12 orang $(63,2 \%)$ ada pada kategori normal dan sebanyak 7 orang $(36,8 \%)$ ada pada kategori tidak normal

Berdasarkan data tersebut, peneliti berpendapat bahwa bayi yang diberi ASI Eksklusif cenderung mempunyai lingkar kepala yang normal dibandingkan dengan bayi yang tidak diberi ASI Eksklusif. Hasil penelitian menunjukkan bahwa semua balita tidak mengalami gangguan pertumbuhan otak tidak ada responden yang mengalami gangguan seperti hidrosefalus, mikrosefalus, ataupun makrosefalus. Tujuan pengukuran lingkar kepala anak adalah untuk mengetahui lingkaran kepala anak dalam batas normal atau diluar batas normal. 
Pertumbuhan ukuran lingkar kepala bayi dengan mengukur dan memantau, kelainan-kelainan yang mungkin saja terjadi pada otak akan segera bisa dideteksi, seperti mikrosefali yaitu ukuran lingkar kepala lebih kecil dari ukuran lingkar kepala normal atau makrosefali ukuran lingkar kepala lebih besar daripada ukuran lingkar kepala normalnya.

Hasil penelitian ini sejalan dengan penelitian yang dilakukan oleh Kumala Dewi (2015) yang menyatakan bahwa bayi yang tidak diberikan ASI eksklusif memiliki pertumbuhan berdasarkan pengukuran lingkar kepala semua tidak normal sebanyak 3 responden (11,11\%). Bayi yang diberikan ASI eksklusif memiliki pertumbuhan berdasarkan pengukuran lingkar kepala semua normal sebanyak 16 responden (59,25\%).

Pertumbuhan merupakan bertambahnya jumlah dan besarnya sel di seluruh tubuh secara kuantitatif dapat diukur (Hidayat, 2008). Pada bayi yang diberi susu formula apabila penanganan dan ketidaktahuan indikasi penggunaan yang tepat maka dapat menyebabkan malnutrisi dan gangguan pertumbuhan sedangkan bayi yang diberi ASI eksklusif sampai usia 6 bulan berdasarkan bukti ilmiah akan tercukupinya kebutuhan bayi dan baiknya pertumbuhan bayi serta menurunnya morbiditas bayi (Sofyana, 2011).

Bayi yang mendapatkan ASI eksklusif umumnya akan mengalami pertumbuhan yang pesat, namun lebih lambat dibandingkan bayi yang mendapat ASI non eksklusif. Hasil penelitian retrospektif di Baltimore- Washington DC bahwa dalam kondisi yang optimal, ASI eksklusif mendukung pertumbuhan bayi selama 6 bulan pertama sehingga status gizi mencapai normal. Bayi yang mendapat gizi adekuat akan mengalami peningkatan berat badan rata-rata sebesar: 700-1000 gram/bulan pada triwulan I dan 500-600 gram/bulan pada triwulan II. Sedangkan untuk panjang badan bayi yang baru lahir rata-rata adalah $50 \mathrm{~cm}$, dan umumnya pertambahan panjang badan anak mencapai 1,5 x tinggi badan lahir saat umur 1 tahun

Pertumbuhan antara berat badan dan tinggi badan ada hubungan yang linear jika pertumbuhan anak normal. Pemberian ASI saja juga dapat mempengaruhi peningkatan berat badan dan tinggi badan agar pertumbuhan seimbang. Anak yang diberi ASI eksklusif pertumbuhannya akan lebih baik dibandingkan dengan anak yang tidak diberi ASI eksklusif. Pertumbuhan anak berhubungan dengan kebutuhan gizi, jika gizi yang diperlukan dalam proses pertumbuhan tidak seimbang, maka anak-anak akan mengalami gizi kurang atau buruk pada masa pertumbuhan balita (Abdullah,2012).

Hal tersebut bisa terjadi karena zat gizi yang terkandung dalam ASI sesuai dengan kebutuhan bayi. Pertumbuhan bayi sebagian besar ditentukan oleh jumlah ASI yang diperoleh, termasuk energi dan zat gizi lainnya yang terkandung di dalam ASI tersebut (Maryunani, 2012).

ASI memiliki banyak manfaat untuk bayi, oleh karenanya dianjurkan untuk menyusui bayi secara eksklusif selama 6 bulan dan tetap melanjutkan menyusui sampai anak berusia 2 tahun. Manfaat ASI sudah tidak diragukan lagi karena kandungan dalam ASI yang luar biasa dan tidak terdapat pada jenis susu apapun (Adiningrum, 2014).

Berbagai studi menunjukkan bahwa gangguan pertumbuhan telah terjadi sejak enam bulan pertama kehidupan bayi. Masalah gangguan pertumbuhan anak usia dini dapat terjadi akibat kekurangan gizi, dan kurang gizi dapat terjadi dari beberapa akibat yaitu ketidak seimbangan asupan zat- zat gizi, faktor penyakit pencernaan, absorbsi dan penyakit infeksi. Keadaan gizi dapat dipengaruhi oleh keadaan fisiologis dan juga oleh keadaan ekonomi sosial, politik dan budaya. Dampak kekurangan gizi terhadap tumbuh kembang anak telah cukup disadari 
oleh berbagai kalangan. Anak-anak yang kekurangan gizi akan mengalami gangguan pertumbuhan fisik, mental dan intelektual. Gangguan tersebut menyebabkan tingginya angka kematian dan kesakitan, serta berkurangnya daya tahan tubuh. Kekurangan gizi pada usia dini mempunyai dampak yang buruk pada masa dewasa dan dimanifestasikan dalam bentuk fisik yang lebih kecil dengan produktifitas yang lebih rendah (Abdullah, 2012).

Penelitian Megawati (2012), didapatkan bahwa bayi yang tergolong pertumbuhannya tidak normal paling banyak pada bayi yang tidak diberi kolostrum yakni 58,8 \%, dan menurut penelitian dari Sucipto (2012), didapatkan hasil bahwa dari 122 bayi yang mendapatkan ASI eksklusif sebagian besar $(95,10 \%)$ memiliki berat badan normal dan sebagian kecil mengalami pertumbuhan berat badan lebih $(2,45 \%)$ dan pertumbuhan berat badan kurang yaitu sebesar 2,45 persen. Dan yang tidak mendapatkan ASI eksklusif sebagian besar $(68,57 \%)$ mengalami berat badan yang kurang dan sebagian kecil $(5,71 \%)$ mengalami pertumbuhan berat badan yang normal, sedangkan yang mengalami berat badan sangat kurang yaitu sebanyak 28,12 persen.

Hal ini sejalan dengan pendapat Suradi dkk (2010) yang menyatakan bahwa Air Susu Ibu (ASI) merupakan nutrisi ideal untuk menunjang kesehatan, pertumbuhan dan perkembangan bayi secara optimal. ASI akan mencegah malnutrisi karena ASI mengandung zat-zat gizi yang dibutuhkan bayi dengan tepat, mudah digunakan secara efisien oleh tubuh bayi dan melindungi bayi terhadap infeksi. Tahun pertama kehidupan bayi sistem kekebalan bayi belum sepenuhnya berkembang dan tidak bisa melawan infeksi seperti halnya anak yang lebih besar atau orang dewasa, oleh karena itu zat kekebalan yang terkandung dalam ASI sangat berguna. Manfaat ASI untuk kesehatan bayi tidak perlu diragukan lagi karena sudah banyak bukti ilmiah yang menunjukkan bayi yang mendapat ASI terhindar dari malnutrisi, baik kurang gizi maupun lebih gizi (overweight dan obesitas), mempunyai kecerdasan lebih, mempunyai daya tahan yang lebih baik terhadap penyakit dan masih banyak manfaat positif lain dari ASI terhadap tumbuh kembang anak

Berdasarkan hal tersebut, dapat disimpulkan bahwa dengan pemberian ASI Eksklusif sangat mempengaruhi berat badan, tinggi badan, dan lingkar kepala yang sangat mempengaruhi terhadap pertumbuhan bayi yang dapat dilihat dari keseluruhan dikatakan normal.

\section{Perkembangan Anak Usia 12 Bulan}

Berdasarkan hasil penelitian ini menunjukkan bahwa sebagian besar anak usia 12 bulan di Desa Barumekar Kecamatan Parungponteng Kabupaten Tasikmalaya ada pada kategori sesuai, hanya 16,7\% yang mengalami perkembangann tidak sesuai. Hal ini disebabkan karena sebagian anak yang tidak sesuai perkembangannya tidak diberi ASI Eksklusif. Perkembangan anak usia 12 bulan yang tidak normal dapat dilihat dari hasil observasi dengan menggunakan KPSP dapat dilihat bahwa anak belum dapat mengucapkan 2 suku kata seperti ma-ma, selain itu anak belum dapat berdiri selama 30 detik atau lebih dengan berpegangan pada meja, dan tidak dapat menemukan seseorang yang bersembunyi. Ini terjadi karena motorik halus dan motorik kasar yang terjadi pada anak tersebut masih berkembang. Perkembangan motorik halus dan motorik kasar dapat dirangsang dengan diberikan ASI Eksklusif.

Berdasarkan data tersebut, peneliti berpendapat bahwa pemberian ASI secara eksklusif mempengaruhi perkembangan karena ASI mempunyai kandungan yang baik untuk 
perkembangan anak selain itu pemberian ASI juga dapat menjadi stimulasi untuk perkembangan anak hal ini dikarenakan pada saat menyusui anak dan ibu berinteraksi sehingga membentuk perkembangan anak. Selain dari pemberian ASI juga dipengaruhi oleh adanya stimulasi dari lingkungan sekitar.

Pada penelitan Exclusive Breastfeeding And Develpmental And Behavior Status In Early Childhood menyatakan bahwa hasil dari penelitiannya menunjukkan adanya hubungan antara pemberian ASI eksklusif dan perkembangan. Dalam

penelitian The Impact of Nutrition on Child Development at 3 Years in a Rural Community of India juga menyatakan bahwa terdapat hubungan pemberian ASI eksklusif dengan perkembangan anak pada usia dibawah 1 tahun dan perbaikan gizi yang baik pada anak yang diberikan ASI eksklusif dibandingkan dengan yang tidak ASI eksklusif. Adapun pada penelitan Breastfeeding and Child Cognitive Development menyatakan ada hubungan signifikan antara pemberian ASI eksklusif terhadap perkembangan dimana pada anak usia 12 bulan yang diberikan ASI eksklusif memiliki tingkat kognitif yang baik (Kramer et al, 2008). Pernyataan tersebut sesuai dengan pendapat Suradi dkk (2010) yang menyatakan bahwa kebutuhan nutrisi untuk optimalisasi pertumbuhan dan perkembangan menjadikan tata laksana nutrisi bayi baru lahir menjadi suatu tantangan tersendiri. Melakukan rawat gabung segera pada bayi baru lahir sangat penting dalam memulai kegiatan menyusui. Pelayanan ini kelihatannya sederhana tapi sangat membantu ibu dan bayi untuk sukses melewati masamasa sulit di awal kelahiran. Ibu mengenal tanda-tanda bayi ingin minum, dan segera memberinya pada bayi hingga bayi bisa menyusu kapan saja. Air susu ibu memiliki banyak manfaat untuk bayi, oleh karenanya dianjurkan untuk menyusui bayi secara eksklusif selama 6 bulan dan tetap melanjutkan menyusui sampai usia anak 2 tahun.

Menurut Khamzah (2012), pemberian ASI merupakan hal penting dalam tumbuh kembang anak karena di dalam ASI terdapat kandungan minyak omega-3 asam linoleat alfa yang sangat dibutuhkan bagi perkembangan anak dan tidak terdapat pada susu formula . Anak yang mendapatkan ASI sampai berusia 6 bulan akan lebih cepat berkembang dibandingkan dengan anak yang tidak diberikan ASI karena ASI mengandung unsur-unsur gizi yang dibutuhkan oleh anak agar anak dapat berkembang secara optimal. Pemberian ASI berperan penting terhadap perkembangan anak sesuai dengan tahapan usianya, jika pemberian ASI pada anak kurang maka perkembangan anak cenderung akan menyimpang.

Hal ini sesuai teori yang dikemukakan oleh Diah (2012), bahwa keuntungan dari pemberian ASI eksklusif adalah bayi mengalami pertumbuhan dan perkembangan yang sesuai dengan umur, terbentuknya ikatan batin yang kuat, serta meminimalkan resiko bayi terserang penyakit pencernaan, pernafasan, dan lain-lain.

Berdasarkan uraian tersebut, dapat disimpulkan bahwa pemberian ASI Eksklusif dapat menunjang terhadap perkembangan anak usia 12 bulan, sedangkan yang tidak diberi ASI Eksklusif ada beberapa orang yang meragukan. Ini menunjukkan bahwa ASI Eksklusif dapat berperan terhadap perkembangan anak.

\section{F. KESIMPULAN}

Berdasarkan hasil penelitian dan pembahasan, maka dapat disimpulkan sebagai berikut :

1. Pertumbuhan anak usia 12 bulan yang diberikan ASI Eksklusif di Desa Barumekar Kecamatan Parungponteng Kabupaten Tasikmalaya periode Maret-April tahun 2017 ada pada 
kategori normal sebesar 100\%, sedangkan yang tidak diberi ASI Eksklusif ada pada kategori tidak normal sebesar $36,8 \%$.

2. Perkembangan anak usia 12 bulan yang diberi ASI Eksklusif di Desa Barumekar Kecamatan Parungponteng Kabupaten Tasikmalaya periode Maret-April tahun 2017 ada pada kategori sesuai sebesar 100\%, sedangkan yang tidak diberi ASI Eksklusif hanya beberapa orang yang meragukan $15,8 \%$.

\section{G. DAFTAR PUSTAKA}

Ambarwati, Wulandari. 2009. Susui Aku. Bayi Sehat dan Cerdas dengan ASI. Khazanah Intelektual. Bandung.

Arifin,2004.ManfaatASI.(diunduh,17Januari2017)tersediadari:http://www.kaunee.com.

Danuatmadja, 2007. Proses Produksi ASI. Keluarga Sehat Keluarga Bahagia. (diunduh,20Januari2017)tersediadari:http://babywonderful.blogspot.com/2009/03/prosesproduksi-asi.html

Danuatmadja, 2007. Proses Produksi ASI. Keluarga Sehat Keluarga Bahagia. (diunduh, 20 Januari 2017) tersedia dari: http://babywonderful.blogspot.com/2009/03/proses-produksiasi.html

J.W. Santrock, 2007. Psikologi Perkembangan.Edisi 11 Jilid 1. Jakarta: Erlangga.

Juli Jumadi, 2015. Hubungan Pemberian ASI Eksklusif dengan Tidak ASI Eksklusif Terhadap Perkembangan Anak Usia 3-12 Bulan. Jurnal Penelitian. Diakses tanggal 15 Januari 2017.

Kurniasih, 2008. Air Susu Ibu. Wikipedia Bahasa Indonesia, Ensiklopedi Bebas. (diunduh, 20 Januari 2017) tersedia dari: www. Infoibu. Com

Nursalam dkk, 2005. Asuhan keperawatan bayi dan anak (untuk perawat dan bidan) Edisi 1. Jakarta: Salemba Medika

Pediatrics. 2006. Breastfeeding And The Use Of Human Milk. Pediatrics. 115: 496- 506.

Perry \& Potter, 2005. Buku Ajar Fundamental Keperawatan : Konsep, Proses, dan Praktik

.Edisi 4. Volume 2.Alih Bahasa : Renata Komalasari, dkk. Jakarta:EGC

Prasetyono, 2009. Air Susu Ibu. Tinjauan dari Beberapa Aspek. FK-UI. Jakarta

Raspy, 2007. Hubungan Antara ASI Eksklusif Dengan Pertumbuhan Bayi. Fakultas Kedokteran. UMS. 2008. (diunduh, 20 Januari 2017) tersedia dari: www.kumpulanmakalah.com/UMS.htmlv

Roesli, 2008. Mengenal ASI Eksklusif. Jakarta: Trubus Agriwidya

Soekirman, 2000. Ilmu Gizi dan Aplikasinya: untuk Keluarga dan Masyarakat.Jakarta:

Sofyana, 2011. Perbedaan Dampak Pemberian Nutrisi ASI Eksklusif dan Non Eksklusif Terhadap Perubahan Ukuran Antropometri dan Status Imunitas pada Neonatus di Rumah Sakit Umum Daerah (RSUD) Al Ihsan Provinsi Jawa Barat. Thesis

Supariasa, 2010. Penilaian Status Gizi, Jakarta:EGC.

Suradi, 2004. Manajemen Laktasi. Program Manajemen Laktasi Perkumpulan Perinatologi Indonesia. Jakarta. 
Susilowati, 2008. Pengukuran Status Gizi Dengan Antropometri Gizi. Jakarta : CV. Trans Info Media.

Tyas, 2013. Hubungan antara Pemberian ASI Eksklusif dan ASI Non Eksklusif dengan Pertumbuhan Berat Badan Bayi 0-6 Bulan di Desa Giripurwo Wonogiri. Skripsi.

Utaminingrum \& Sartono, 2012. Hubungan Pengetahuan Ibu, Pendidikan Ibu dan Dukungan Suami dengan Praktek Pemberian ASI Eksklusif di Kelurahan Muktiharjo Kidul Kecamatan Telogosari Kota Semarang. Jurnal Gizi Universitas Muhammadiyah Semarang Wong, dkk ,2008. Buku Ajar Keperawatan Pediatrik ed.6 volume 1, Jakarta: EGC Yandi Locitasari, 2015. Perbedaan Pertumbuhan Bayi Usia 0-6 Bulan Yang Diberi ASI Eksklusif Dengan Yang Diberi Susu Formula Di Kecamatan Ngawi. Jurnal Penelitian. Diakses tanggal 15 Januari 2017. 